\title{
Intelligent Urban Sustainable Development Plan
}

\author{
Zaiqiang Ku, Ting Liao* \\ College of Mathematics and Physics, Huanggang Normal University, Huanggang, China \\ Email: *kzqhgnu@163.com
}

How to cite this paper: Ku, Z.Q. and Liao, T. (2017) Intelligent Urban Sustainable Development Plan. Journal of Applied Mathematics and Physics, 5, 1044-1056. https://doi.org/10.4236/jamp.2017.55092

Received: April 6, 2017

Accepted: May 15, 2017

Published: May 19, 2017

Copyright $\odot 2017$ by authors and Scientific Research Publishing Inc. This work is licensed under the Creative Commons Attribution International License (CC BY 4.0).

http://creativecommons.org/licenses/by/4.0/

\begin{abstract}
Based on the entropy weight method and the gray relational analysis method, we first calculate the weight of each index and the correlation coefficient between the indicators, get the urban intelligent growth index, and then calculate the annual growth rate of the composite index. We find the following results. First, Suzhou to improve its environment, the success rate of $109.67 \%$. Saint Louis to improve its economy, the growth rate of $57.4 \%$. Second, the sensitivity of the data analysis, each of the indicators is increased by $10 \%, 20 \%$, $30 \%$, other indicators remain unchanged. Recalculate the city's intelligent growth index, we find that the greater the volatility, the greater the potential. The total population of the city, built green area, the total length of the bus operating a greater potential, built-up area, the smallest regional GDP potential. Finally, we propose an improved model combining remote sensing with GIS to analyze urban expansion and farmland loss from time and space qualitatively and quantitatively.
\end{abstract}

\section{Keywords}

Sustainable, Entropy Weight Method, Gray Relational Analysis Method, GIS

\section{Introduction}

The discussion around the cities and their development has never stopped. Moving from the "industrial city" to the "city of services" and, finally, to contemporary urban conurbations, the city has indeed experimented issues of a different nature related to its growth. In these years of "urban re-concentration" social problems have emerged, related to the provision of essential services such as housing and education at an affordable cost, a social environment without crime, safe and inclusive [1] [2] [3]. In response to these challenges, after the models of urban sustainability represented by the "green city" and the "creative 
city", taking shape new paradigm for the modern city, the "smart growth city" [4].

Many communities are implementing smart growth initiatives in an effort to consider long range, sustainable planning goals [5]. Smart growth covers a range of development and conservation strategies that help protect our health and natural environment and make our communities more attractive, economically stronger, and more socially diverse [6]. Smart growth focuses on building cities that embrace the sustainability-economically prosperous, socially equitable, and environmentally sustainable. This task is more important than ever because the world is rapidly urbanizing. It is projected that by 2050, 66 percent of the world's population will be urban-this will result in a projected 2.5 billion people being added to the urban population [7].

Smart growth of a city has 10 principles [8], which must be tailored to a community's unique needs to be effective. In general, any measure of success must incorporate the demographics, growth needs, and geographical conditions of a city [9]. Zhang et al. [10] considered that the exploitation of residual coal can effectively delay China's coal depletion, inhibit the construction of new mines, redress the imbalance between supply and demand of coal in eastern China, improve the mining area environment and guarantee social stability. Tan et al. [11] considered different development categories including economic, social and environmental factors with different indicators. Lin et al. [12] aimed to integrate performance and importance levels using quantitative and qualitative information with a modified balanced scorecard model. Zhao et al. [13] proposed the concepts and associated contents of land senses ecology and mismatching data. Therefore, this paper investigates how to use smart growth theory to measure the smart growth degree of two cities-Suzhou and Sao Luis. Particularly, we want to answer the following questions.

1) How to define a metric to measure the success of smart growth of a city, which considers the three E's of sustainability and/or the 10 principles of smart growth?

2) Research the current growth plan of the selected cities. Measure and discuss how the current growth plan of each city meets the smart growth principles. How successful are the current plans according to our metric?

3) Suppose the population of each city will increase by an additional $50 \%$ by 2050 , explain in what way(s) our plan supports this level of growth?

The rest of this paper is organized as follows. In Section 2, we describe some assumptions and notations of the model. In Section 3, we discuss the evaluation system of smart growth city. In Section 4, we put forward the current development plan evaluation. In Section 5, we give the city plans for future growth. Some extensions are given in Section 6. Finally, some conclusions are made in Section 7.

\section{Assumptions and Notations}

In order to establish the model, we make the following assumptions, which have 
been used extensively in Chen et al. [14], Cheng et al. [15], Thomas [16], Liu et al. [17], Zhang et al. [18], and Yang et al. [19].

1) The selected city is representative. The development of the city is relatively stable and smooth, which can be used to represent the majority of the development of the city.

2) We assume that the selected city have no natural disasters, the city government has stable which is not easily suffer the natural disasters and without help. We choose the city has not exist regime instability and conflict, which can be used to do research for the sustainable development of city, and it only depends on the development of its government without external force.

3) The reliable and persuasive data. We search the strong credibility information released data from the government's official website.

In order to model the above mentioned problem, the following notations are employed (Table 1).

\section{Evaluation System of Smart Growth City}

Smart growth aims to help each town and city into a more prosperity, social justice, environmental and economic sustainable development of the city. According to the three principles of city sustainable development that are economic prosperity, social equity and environmental sustainable development to determine the index of city smart growth composite index.

Table 1. The list of notations.

\begin{tabular}{|c|c|}
\hline Symbol & Definition \\
\hline$A_{1}$ & GDP \\
\hline $\mathrm{A}_{2}$ & The total amount of import and export \\
\hline $\mathrm{A}_{3}$ & The total export \\
\hline $\mathrm{B}_{1}$ & The city s population \\
\hline $\mathrm{B}_{2}$ & The basic old age insurance number \\
\hline $\mathrm{B}_{3}$ & Every one thousand people with health agency data \\
\hline $\mathrm{B}_{4}$ & Professional and technical personnel \\
\hline $\mathrm{B}_{5}$ & Urban built up area \\
\hline $\mathrm{B}_{6}$ & The bus operating line the total length \\
\hline $\mathrm{B}_{7}$ & Taxi operation vehicle \\
\hline $\mathrm{C}_{1}$ & Built up area green area \\
\hline $\mathrm{C}_{2}$ & Intensity of sulfur dioxide emissions per unit of GDP \\
\hline $\mathrm{C}_{3}$ & Industrial waste water processing \\
\hline$X_{i j}$ & The ith object the jth index \\
\hline$w$ & Weights \\
\hline$\xi$ & Correlation coefficient \\
\hline
\end{tabular}




\subsection{The Establishment of City Smart Growth Evaluation}

The science evaluation system is the basis of economic prosperity, social justice and the sustainable development of environment. The establishment of integrated city smart growth evaluation must follow the following principles: economic prosperity, social justice and environmental sustainable development.

According to these principles, we will take the success of the city smart growth degree as the primary. Intelligent economy, intelligent community, intelligent environment as a secondary indicator. GDP, the total amount of import and export, total export, the city's total population, the number of primary endowment insurance, every one thousand people have health organization personnel, professional and technical personnel and city built-up.

\subsection{The Reason of Select Indicators}

A city economic levels, is mainly reflected in the GDP, the total import and export, export volume.

A city intelligent level of socialization, mainly reflected in the city's total population, the number of primary endowment insurance. The basic old-age insurance number, professional and technical personnel, city built-up area, bus line.

A city economic environment optimization degree mainly reflected in the built up area of green area. The intensity of sulfur dioxide emissions per unit of GDP, industrial waste water processing.

\section{The Current Development Plan Evaluation}

First, through the entropy weight method to determine the weight of each index, according to grey correlation analysis method to calculate the intelligent economic index, smart and intelligent environmental index, and social index for smart economic index, intelligent community, and intelligent environment index accumulation is obtained.

A soft computational program, SPSS was designed and run in the personal computer with Intel ${ }^{\oplus}$ Core (TM) 2 Duo CPU T7700, $2.40 \mathrm{GHz} 2.39 \mathrm{GHz}$ and RAM 1.99 GB.

\subsection{The Establishment of Comprehensive City Smart Growth Index}

Empowerment of entropy method [5] is a method of weight in the evaluation, through the calculate the weight of entropy which is based on the differences of the various evaluation index, determine the weight of each evaluation index. We use the entropy weight method and gray correlation analysis method combined with the method to determine the comprehensive index.

\subsubsection{The Entropy Weight Method to Establish Weights}

In the methodology of information, entropy is a measure of uncertainty thing. Among, the information quantity is greater, the uncertainty value and entropy is smaller. According to its characteristics, can calculate the entropy tell the ran- 
dom and disorder of a certain event, entropy value can also be used to determine a index of discrete degree, if the index in the degree of discrete is greater, the influence of the index of comprehensive evaluation is greater.

Degree of variation information entropy index for reaction, so as to make a comprehensive evaluation. This paper use the software to standardize city from 2010 to 2015 data processing, then use of entropy method to calculate three-level indicator GDP, the total import and export, export volume, the city's total population, the number of primary endowment insurance. The total length of the taxi operating vehicles, built up area green area, the strength of sulfur dioxide emissions per unit of GDP, the rate of industrial waste water weight, specific steps are as follows.

1) According to the formula $p_{i j}=\frac{x_{i j}}{\sum_{i=1}^{m} x_{i j}}$

2) Calculation index $x_{i j}$ weight $p_{i j}$ under index $j$.

3) According to the formula $e_{j}=-k \sum_{i=1}^{m} p_{i j} \ln p_{i j}$ of index $j \operatorname{entropy}\left(e_{j}\right)$, $k=\frac{1}{\ln m}$.

4) According to the formula $d_{j}=1-e_{j}$, to calculate index $\mathrm{j}$ factor the difference of the $d_{j}$.

5) According to formula $w_{j}=\frac{d_{j}}{\sum_{j=1}^{n} d_{j}}$, to calculate the weight of each index $j$.

It is concluded that the index weight in Suzhou as

A1: 0.0264, A2: 0.0021, A3: 0.0039, B1: 0.0003, B2: 0.024, B3: 0.8539, B4: 0.047, B5: 0.0019, B6: 0.0235, B7: 0.0118, C1: 0.0032, C2: 0, C3: 0.002 .

It is concluded that each index weight in Saint Louis as

A1: $0.0069, \mathrm{~A} 2: 0.0254, \mathrm{~A} 3: 0.8795, \mathrm{~B} 1: 0.0107, \mathrm{~B} 2: 0.0002, \mathrm{~B} 4: 0.0003$, B5:0.0042, B6: 0.0474, C1: 0.013, C2: 0.0112, C3: 0.0011.

\subsubsection{Grey Correlation Analysis}

Grey correlation analysis method is one way to measure the correlation degree between the factors. Grey correlation theory is a certain method, the grey relational analysis of various factors in the concept, to seek the numerical relationship between the various factors in the system [1]. Therefore, the grey correlation analysis to the development of a system change situation provides a quantitative measure, very suitable. This paper using the grey correlation analysis method, calculates the economic index of the urban intelligent respectively, intelligent social index, intelligent environment index of the relationship between the coefficient matrix, combined with the weight of each evaluation index to calculate comprehensive index of city smart growth.

Seen from the Table 2 and Table 3, the smart growth of Suzhou composite index generally on the rise, and Saint Louis smart growth index have been substantially rise after falling. 
Table 2. Suzhousmart growth index from 2010 to 2015 growth.

\begin{tabular}{ccccc}
\hline Year & $\begin{array}{c}\text { Intelligent } \\
\text { economic index }\end{array}$ & $\begin{array}{c}\text { Intelligent social } \\
\text { index }\end{array}$ & $\begin{array}{c}\text { Intelligent } \\
\text { environment index }\end{array}$ & $\begin{array}{c}\text { Composite index } \\
\text { of growth }\end{array}$ \\
\hline 2010 & 0.1077 & 0.0484 & 0.0492 & 0.2053 \\
2011 & 0.1613 & 0.0569 & 0.0658 & 0.2846 \\
2012 & 0.2188 & 0.0800 & 0.1292 & 0.4284 \\
2013 & 0.2299 & 0.0873 & 0.0906 & 0.4078 \\
2014 & 0.3170 & 0.1412 & 0.0577 & 0.5159 \\
2015 & 0.3232 & 0.1451 & 0.0431 & 0.5114 \\
\hline
\end{tabular}

Table 3. Saint Louis smart growth index from 2010 to 2015 growth.

\begin{tabular}{ccccc}
\hline Year & $\begin{array}{c}\text { Intelligent } \\
\text { economic index }\end{array}$ & $\begin{array}{c}\text { Intelligent social } \\
\text { index }\end{array}$ & $\begin{array}{c}\text { Intelligent } \\
\text { environment index }\end{array}$ & $\begin{array}{c}\text { Composite index } \\
\text { of growth }\end{array}$ \\
\hline 2010 & 0.4263 & 0.0704 & 0.0704 & 0.5671 \\
2011 & 0.1758 & 0.0802 & 0.0802 & 0.3362 \\
2012 & 0.1584 & 0.0929 & 0.0929 & 0.3442 \\
2013 & 0.1426 & 0.1122 & 0.1122 & 0.3676 \\
2014 & 0.1531 & 0.1447 & 0.1447 & 0.4425 \\
2015 & 0.1421 & 0.2113 & 0.2113 & 0.5647 \\
\hline
\end{tabular}

\subsection{The Composite Index}

City are calculated respectively from 2011 to 2015, the intelligence of year-onyear growth in 2015 composite index of growth, judging by city smart growth each year growth rate of the composite index of growth. When the growth rate is greater than 0, the Suzhou current plan is a success, on the other hand is failure.

Seen from the diagram (Figure 1), Suzhou composite index of growth is changing, as in 2013 and 2015, the growth rate is negative, is not in conformity with the current growth plan. 2011, 2012, 2014, growth is positive, in line with the current growth plans. And Saint Louis composite index growth rate rising, but in 2011, the growth rate is negative, is not in conformity with the current growth plan, 2012 to 2015 annual growth rate is positive, in line with the current growth plans.

\section{City plans for Future Growth}

According to the city's geographic location, economic opportunities and the comprehensive analysis of the expected rate of growth to make growth plans by 2050 .

\subsection{Growth Plan in Suzhou}

\subsubsection{Location}

Suzhou construction land scale has reached 2432 square kilometers, accounting for $28.1 \%$ of the city area, accounting for $49.8 \%$ of the land area accounting for $80.7 \%$ of the construction land area. 


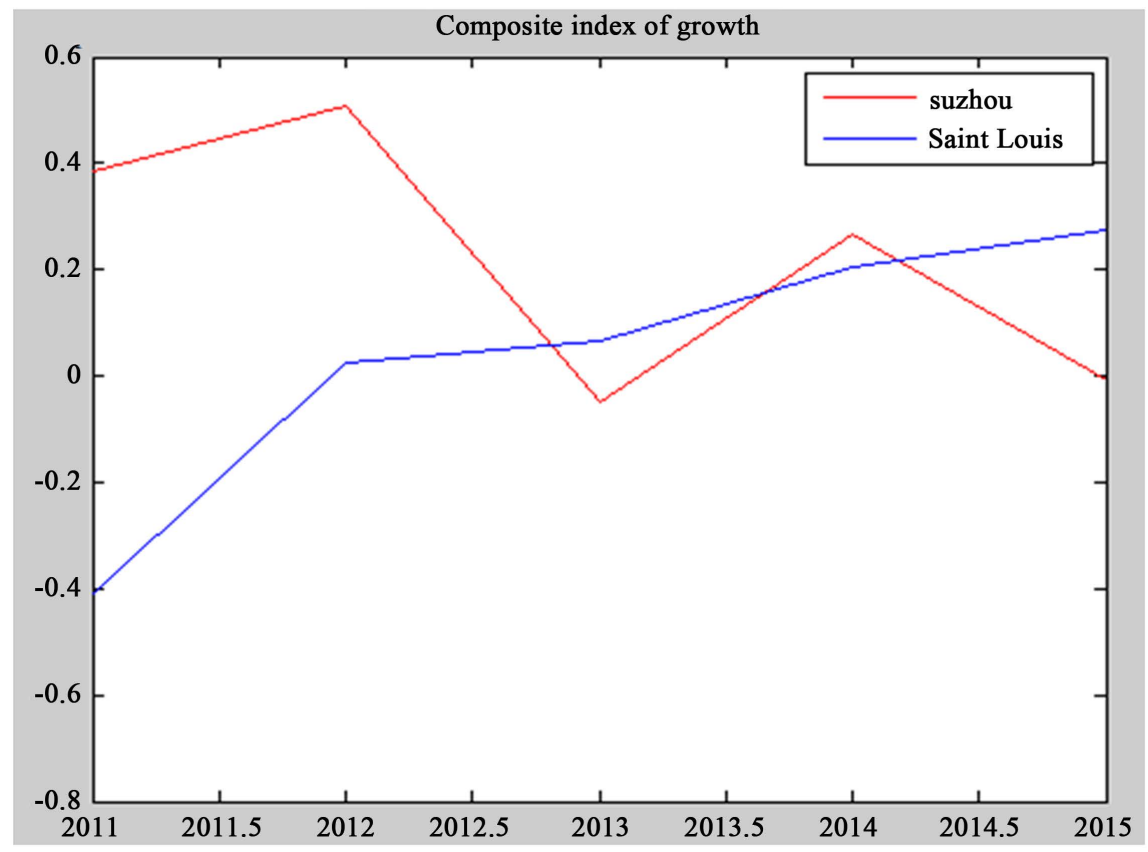

Figure 1. Composite index of growth.

Rapid consumption of land resources has broken through the planning and control the size of the index of land. Population scale and facilities are difficult to support. It is worth noting that area traffic location advantage is being weakened in Suzhou, reach the internal plates scattered independent development, rapid transport links support is insufficient, the urban centricity is not strong. Urban traffic organization still keep ancient city as the core, close to the limit capacity, and contradict with ancient city protection. Aiming at this problem, we should control of urban area, the maximum use compact, build "bus + go slow" mode of transport, in and out of the old city dominated by rail transit, limit car, lengthen the bus operation of the road long and increase rental operation of the vehicle.

\subsubsection{Economic Opportunities}

In recent years, manufacturing industry is the core of the Suzhou industry and is the most important brand resources. However, Suzhou's manufacturing processing is given priority to, low added value, land input is high, and output efficiency is not high. So, we deal with Suzhou industry to choose and give up. We build transverse promotions, vertical axis agglomeration; science and technology production, and the east side to the west cultural innovation; advanced manufacturing technology of the north of the industry layout structure, improve the GDP, the total import and export and the total exports.

\subsubsection{Expected Rate of Growth}

By counting trends of intelligent community, intelligent economy, intelligent environment from 2010 to 2015, we get the index trend Figure 2.

We can see from Figure 2, the intelligent environment index has been falling since 2012, so we should increase the green area and industrial waste water 


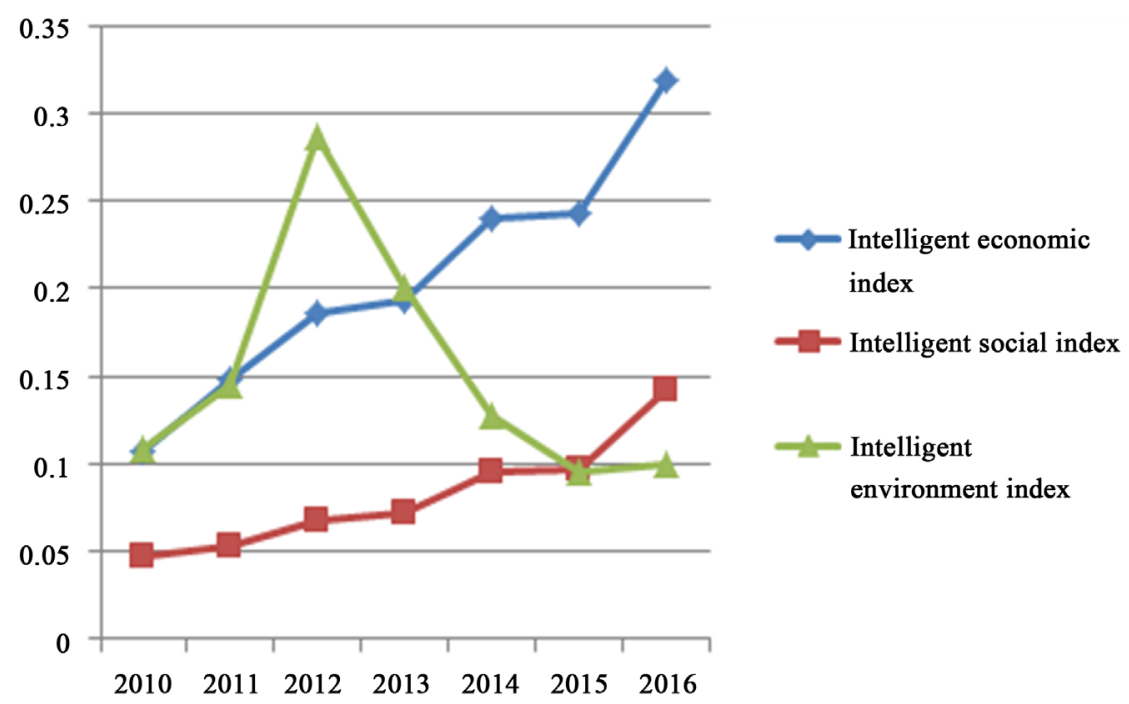

Figure 2. Suzhou index trend diagram.

processing, reduce sulfur dioxide emissions per unit of GDP to strengthen the construction of environment.

\subsubsection{Growth Plan in the Future}

Due to the intelligent economy, the contradiction between the intelligent community and intelligent environment relations. On the other hand, the environment will be growing rapidly. According to the practical problems, Suzhou in the next few decades, should give priority to the environmental protection and at the same time the government should formulate corresponding political measures to promote public participation and promote the urban development in Suzhou.

Here, we propose a bold vision: in 2050 , the GDP growth of $21 \%$, the total import and export growth of $13 \%$, the total export growth of $8 \%, 10 \%$ growth in total population in the city, the basic old-age insurance coverage increased $12 \%$ per one thousand people, and the bus line the total length increased by $7 \%$ growth, taxi operation vehicle.

\subsubsection{Growth Plan Success Degree Evaluation}

We will calculate all the indexes in 2050 based on the original data in 2015 in accordance with the expectations hypothesis respectively, the total GDP import and export, the export volume, the city's total population, the number of primary endowment insurance, each have health organization, professional and technical personnel one thousand people, operating area is, bus lines, the total length of the taxi operating vehicles, built up area green area), the strength of sulfur dioxide emissions per unit of GDP, the rate of industrial waste water prediction, then according to the comprehensive index of the predicted values to assess growth plan, the comprehensive index and composite index in 2015, in order to assess the degree of success of the plan.

It can be seen from Table 4, after the growth and decline of the plan of each index, the smart growth of Suzhou composite index increased significantly and 
Table 4. In 2015 and 2050 composite index in Suzhou.

\begin{tabular}{ccccc}
\hline Year & $\begin{array}{c}\text { Intelligent } \\
\text { economic index }\end{array}$ & $\begin{array}{c}\text { Intelligent social } \\
\text { index }\end{array}$ & $\begin{array}{c}\text { Intelligent } \\
\text { environment index }\end{array}$ & $\begin{array}{c}\text { Composite index } \\
\text { of growth }\end{array}$ \\
\hline 2015 & 0.1905 & 0.1139 & 0.1288 & 0.4332 \\
2050 & 0.3194 & 0.2026 & 0.3863 & 0.9083 \\
\hline
\end{tabular}

in 2015 grew by $109.67 \%$, and on the basis of the judgment of our plan was a great success.

\subsection{Saint Louis Growth Plans}

\subsubsection{Location}

Saint Louis is the only independent city, Missouri, is the state's second largest city. It is located in the Missouri river and the confluence of the Mississippi River, is a transport hub in the American mid-west. Saint Louis has peaked in 1950, the population of 85,6796 people, since the population decrease. It is known that there are more than 200 Saint Louis city logo and the product was identified as historic buildings. When the local repair the buildings, not only to maintain its original true and integrity, still added some modern service function. So we have to increase the number of primary endowment insurance, every one thousand people have health organization, professional and technical personnel, lengthen the bus operation of the road long and increased rental operation of the vehicle.

\subsubsection{Economic Opportunities}

Saint Louis had the important industrial city in the United States and central land and sea transport hub, the Saint Louis's most important industry is the service industry. So we have to increase total GDP, import and export and export volume, in order to improve the intelligent economic comprehensive index.

\subsubsection{Expected Rate of Growth}

By counting trends of intelligent community, intelligent economy, intelligent environment from 2010 to 2015, we get the index trend as shown in Figure 3.

From the diagram, we can see intelligent economic index and intelligent social index fell to a great extent.

\subsubsection{Growth Plan in the Future}

Improve the total GDP, import and export and export volume, reduce the number of population, increasing the size of the basic endowment insurance, every one thousand people with health authorities of beds, professional and technical personnel and operating area is, bus lines, taxi operating vehicles, the total length of proper green area, processing, industrial waste water, reduce sulfur dioxide emissions per unit of GDP.

\subsubsection{Growth Plan Success Degree Evaluation}

With Suzhou growth plan success degree evaluation system, through calculating the forecast of each index, composite index to assess growth plan, the comprehensive index and composite index in 2015, according to projections to assess 


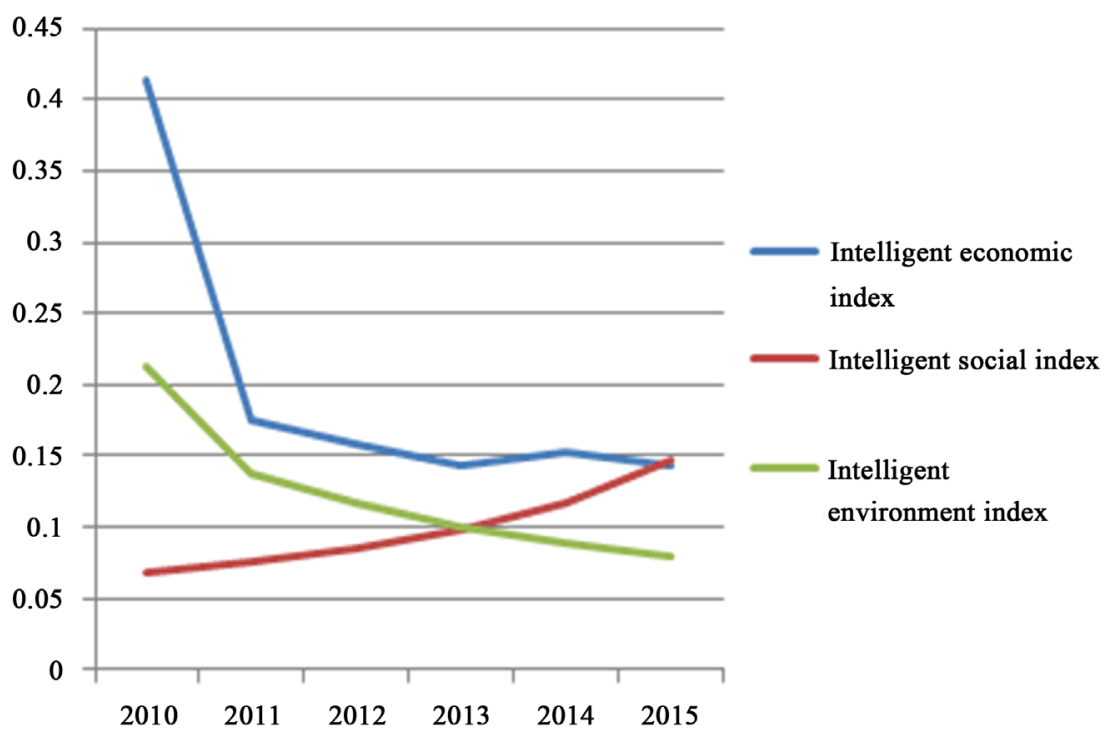

Figure 3. Saint Louis index trend diagram.

growth plan of composite index, calculate its growth rate, growth rate and the ratio of average growth rate of its success.

Can be seen from Table 5, after planning each index of the growth and decline .The smart growth of Suzhou composite index increased significantly, and in 2015 grew by $57.4 \%$, on the basis of the success is $57.4 \%$, so our plan is relatively successful.

\section{Extensions}

Remote sensing is very useful tool that detect and analyze the urban expansion. Using remote sensing data, we can get the latest highway traffic, residential areas, farmland and other data, thus the correct analysis of urban sprawl and farmland loss of spatial relations, this is can't be matched by conventional methods.

Use of geographic space information system (GIS) spatial analysis function, we can quantitative analysis of urban sprawl and the spatial distribution of farmland erosion and impact factor. It is necessary for us to dynamic detect and analyze the diffusion process. As many other geographical phenomena, that the expansion of the city and the process of farmland was invaded can have diffusion theory to explain. Entropy can be used as describe the quantitative indicators of the spatial distribution and change. On the traffic can be easily calculated due to urban expansion caused by the change of entropy, which provides an objective evaluation index.

We can see that urban development and land location and distance factor has great relevance from the remote sensing image clearly. We can take advantage of the exponential function to describe the relationship between the decline of the number of land development and distance

$$
y=a \mathrm{e}^{-b x}
$$

where $x$ is the distance from the city or highway, $y$ is the density of land deve- 
Table 5. In 2015 and 2050 composite index in Saint Louis.

\begin{tabular}{ccccc}
\hline Year & $\begin{array}{c}\text { Intelligent } \\
\text { economic index }\end{array}$ & $\begin{array}{c}\text { Intelligent social } \\
\text { index }\end{array}$ & $\begin{array}{c}\text { Intelligent } \\
\text { environment index }\end{array}$ & $\begin{array}{c}\text { Composite index } \\
\text { of growth }\end{array}$ \\
\hline 2015 & 0.2365 & 0.1492 & 0.1324 & 0.5181 \\
2050 & 0.2397 & 0.1948 & 0.3812 & 0.8155 \\
\hline
\end{tabular}

lopment. Clark has used the function to reflect the population density as a function of the city center distance.

Using GIS buffer analysis function, we can easily establish land development density and away from the highway network and the relationship between the town center distance. First of all, the figure about the present situation of highway and urban dot figure produce different buffer area. Any further using of lamination analysis function of GIS, We remote sensing classification results with lapped up the buffer area, can statistics on the frequency of land development of each buffer area, which can use the regression method to establish land development along with the gradient relationship of these factors.

Shannon formula reflects the amount of information in information theory. Shannon's entropy can be expressed as

$$
H_{n}=\sum p_{i} \log \left(1 / p_{i}\right)
$$

Entropy can be used to describe the geographical phenomenon of dispersion and concentration [8]. First observations $x_{i}$ can be converted to percentages $p_{i}$ :

$$
p_{i}=x_{i} / \sum x_{i}
$$

In order to make the calculated value between 0 and 1 , we can use the following relative entropy to calculate dispersion.

Entropy can be used to describe the geographical phenomenon of dispersion and concentration

$$
H_{n}=\sum p_{i} \log \left(1 / p_{i}\right) / \log n
$$

Relative to the concentration degree of dispersion can be expressed as:

$$
c_{n}=1-H_{n}
$$

Dispersion value shows that the expansion of the city is chaotic, the lack of a reasonable standard layout.

As many other geographical phenomena, the development of the city appears as a diffusion process. Due to the needs of economic development and population growth, urban sprawl, cause the city periphery and highway near the farmland has been siphoning off and become the new urban land. This diffusion process can be explained by the diffusion theory, while long phase of satellite remote sensing image provides the feasibility of this analysis. Diffusion theory is widely applied to explain information, new technology and the spread of the disease or transmission process. Urban sprawl reflects a series of natural and social factors. In time by remote sensing images can clearly see, land development in the pearl river delta is usually along the edge of the city and highway quickly 
spread outward. We can calculate long phase of remote sensing image on the change of the entropy value of urban land to monitor process of

$$
\begin{aligned}
\Delta H & =H(t+1)-H(t) \\
& =\sum p_{i}(t+1) \log \left(1 / p_{i}(t+1)\right) / \log n-\sum p_{i}(t) \log \left(1 / p_{i}(t)\right) / \log n
\end{aligned}
$$

The increase of entropy shown urban land spread outward. The faster increase in value, the greater said diffusion. The decrease of entropy shown urban land tends to be more "compact".

\section{Conclusions}

In this paper, the weight of each index and the correlation coefficient between the indicators was calculated based on the entropy weight method and the gray relational analysis method. The urban intelligent growth index and the annual growth rate of the composite index were also calculated. Based on the research, an improved model combining remote sensing with GIS to analyze urban expansion and farmland loss from time and space qualitatively and quantitatively was proposed.

There are several limitations of the study. First, due to the lack of knowledge and practice of knowledge is not comprehensive, affecting the city smart growth index set is not yet mature. Second we use of entropy method to calculate the weight and the entropy weight method still exist certain defects in the process of calculating weight.

\section{Acknowledgements}

The authors gratefully acknowledge the very helpful comments and suggestions of the editor and the anonymous reviewers for their valuable comments and suggestions that helped improve this paper.

\section{References}

[1] Chen, L., Peng, J. and Zhang, B. (2017) Uncertain Goal Programming Models for Bicriteria Solid Transportation Problem. Applied Soft Computing, 51, 49-59.

[2] Chen, L., Peng, J., Zhang, B. and Li, S. (2017) Uncertain Programming Model for Uncertain Minimum Weight Vertex Covering Problem. Journal of Intelligent Manufacturing, 28, 625-632. https://doi.org/10.1007/s10845-014-1009-1

[3] Chen, L., Peng, J., Zhang, B. and Rosyida, I. (2017) Diversified Models for Portfolio Selection Based on Uncertain Semivariance. International Journal of Systems Science, 48, 637-648. https://doi.org/10.1080/00207721.2016.1206985

[4] Greco, I. and Bencardino, M. (2014) The Paradigm of the Modern City: SMART and SENSEable Cities, for Smart, Inclusive and Sustainable Growth. Computational Science and Its Applications-ICCSA 2014, Springer International Publishing, 579597.

[5] Shannon, C. (1984) A Mathematical Theory of Communication. Bell System Technical Journal, 27, 623-656. https://doi.org/10.1002/j.1538-7305.1948.tb00917.x

[6] EPA (2016) This Is Smart Growth. https://www.epa.gov/smartgrowth/smart-growth-publication 
[7] World Urbanization Prospects (2014) United Nations. https://esa.un.org/unpd/wup/Publications/Files/WUP2014-Highlights.pdf

[8] EPA (2011) Smart Growth: A Guide to Developing and Implementing Greenhouse Gas Reductions Programs.

http://www.sustainablecitiesinstitute.org/Documents/SCI/Report_Guide/Guide_EP A_SmartGrowthGHGReduction_2011.pdf

[9] Lan, B., Peng, J. and Chen, L. (2015) An Uncertain Programming Model for Competitive Logistics Distribution Center Location Problem. American Journal of Operations Research, 5, 536-547. https://doi.org/10.4236/ajor.2015.56042

[10] Zhang, Y., Feng, G., Zhang, M., Ren, H., Bai, J., Guo, Y., Jiang, H. and Kang, L. (2016) Residual Coal Exploitation and Its Impact on Sustainable Development of the Coal Industry in China. Energy Policy, 96, 534-541.

[11] Tan, S., Yang, J., Yan, J., Lee, C., Hashim, H. and Chen, B. (2017) A Holistic Low Carbon City Indicator Framework for Sustainable Development. Applied Energy, 185, 1919-1930.

[12] Lin, M., Hu, J., Tseng, M., Chiu, A. and Lin, C. (2016) Sustainable Development in Technological and Vocational Higher Education: Balanced Scorecard Measures with Uncertainty. Journal of Cleaner Production, 120, 1-12.

[13] Zhao, J., Liu, X., Dong, R. and Shao, G. (2016) Landsenses Ecology and Ecological Planning toward Sustainable Development. International Journal of Sustainable Development \& World Ecology, 23, 293-297. https://doi.org/10.1080/13504509.2015.1119215

[14] Chen, L., Peng, J., Liu, Z. and Zhao, R. (2017) Pricing and Effort Decisions for a Supply Chain with Uncertain Information. International Journal of Production Research, 55, 264-284. https://doi.org/10.1080/00207543.2016.1204475

[15] Cheng, L., Rao, C., Chen, L. and Rosyida, I. (2016) A Belief Degree Constrained Programming Model for Maximum Cut Problem with Uncertain Edge Weights. ICIC Express Letters. Part B, Applications, 7, 1185-1191.

[16] Thomas, R. (1981) Information Statics in Geography. Hutchins \& Sons, Norwich.

[17] Liu, X., Peng, J. and Chen, L. (2015) Uncertain Programming Model for Location Problem of Multi-Product Logistics Distribution Centers. Applied Mathematical Sciences, 9, 6543-6558. https://doi.org/10.12988/ams.2015.59597

[18] Zhang, B., Peng, J., Li, S. and Chen, L. (2016) Fixed Charge Solid Transportation Problem in Uncertain Environment and Its Algorithm. Computers \& Industrial Engineering, 102, 186-197.

[19] Yang, J., Xiao, X., Mao, S., Rao, C. and Wen, J. (2016) Grey Coupled Prediction Model for Traffic Flow with Panel Data Characteristics. Entropy, 18, 454. https://doi.org/10.3390/e18120454 
Submit or recommend next manuscript to SCIRP and we will provide best service for you:

Accepting pre-submission inquiries through Email, Facebook, LinkedIn, Twitter, etc. A wide selection of journals (inclusive of 9 subjects, more than 200 journals)

Providing 24-hour high-quality service

User-friendly online submission system

Fair and swift peer-review system

Efficient typesetting and proofreading procedure

Display of the result of downloads and visits, as well as the number of cited articles Maximum dissemination of your research work

Submit your manuscript at: http://papersubmission.scirp.org/

Or contact jamp@scirp.org 